\title{
The Role of Butyrylcholinesterase and Iron in the Regulation of Cholinergic Network and Cognitive Dysfunction in Alzheimer's Disease Pathogenesis
}

\author{
Jacek Jasiecki ${ }^{1, *(\mathbb{D}}$, Monika Targońska ${ }^{2}$ and Bartosz Wasąg ${ }^{2,3}(\mathbb{D}$ \\ 1 Department of Pharmaceutical Microbiology, Faculty of Pharmacy, Medical University of Gdańsk, \\ 80-416 Gdańsk, Poland \\ 2 Department of Biology and Medical Genetics, Medical University of Gdańsk, 80-210 Gdańsk, Poland; \\ monika.targonska@gumed.edu.pl (M.T.); bwasag@gumed.edu.pl (B.W.) \\ 3 Laboratory of Clinical Genetics, University Clinical Centre, 80-952 Gdańsk, Poland \\ * Correspondence: jjasiecki@gumed.edu.pl
}

check for

updates

Citation: Jasiecki, J.; Targońska, M.; Wasag, B. The Role of

Butyrylcholinesterase and Iron in the Regulation of Cholinergic Network and Cognitive Dysfunction in Alzheimer's Disease Pathogenesis. Int. J. Mol. Sci. 2021, 22, 2033.

https://doi.org/10.3390/ijms22042033

Academic Editor:

Noriyuki Matsukawa

Received: 21 January 2021

Accepted: 16 February 2021

Published: 18 February 2021

Publisher's Note: MDPI stays neutral with regard to jurisdictional claims in published maps and institutional affiliations.

Copyright: (C) 2021 by the authors. Licensee MDPI, Basel, Switzerland. This article is an open access article distributed under the terms and conditions of the Creative Commons Attribution (CC BY) license (https:/ / creativecommons.org/licenses/by/ $4.0 /)$.

\begin{abstract}
Alzheimer's disease (AD), the most common form of dementia in elderly individuals, is marked by progressive neuron loss. Despite more than 100 years of research on AD, there is still no treatment to cure or prevent the disease. High levels of amyloid- $\beta(\mathrm{A} \beta)$ plaques and neurofibrillary tangles (NFTs) in the brain are neuropathological hallmarks of AD. However, based on postmortem analyses, up to $44 \%$ of individuals have been shown to have high A $\beta$ deposits with no clinical signs, due to having a "cognitive reserve". The biochemical mechanism explaining the prevention of cognitive impairment in the presence of $A \beta$ plaques is still unknown. It seems that in addition to protein aggregation, neuroinflammatory changes associated with aging are present in AD brains that are correlated with a higher level of brain iron and oxidative stress. It has been shown that iron accumulates around amyloid plaques in AD mouse models and postmortem brain tissues of AD patients. Iron is required for essential brain functions, including oxidative metabolism, myelination, and neurotransmitter synthesis. However, an imbalance in brain iron homeostasis caused by aging underlies many neurodegenerative diseases. It has been proposed that high iron levels trigger an avalanche of events that push the progress of the disease, accelerating cognitive decline. Patients with increased amyloid plaques and iron are highly likely to develop dementia. Our observations indicate that the butyrylcholinesterase (BChE) level seems to be iron-dependent, and reports show that $\mathrm{BChE}$ produced by reactive astrocytes can make cognitive functions worse by accelerating the decay of acetylcholine in aging brains. Why, even when there is a genetic risk, do symptoms of the disease appear after many years? Here, we discuss the relationship between genetic factors, age-dependent iron tissue accumulation, and inflammation, focusing on AD.
\end{abstract}

Keywords: Alzheimer's disease; butyrylcholinesterase; pseudocholinesterase; iron; IRE; BChE; BuChE; neuroinflammation; amyloid

\section{Introduction}

Alzheimer's disease (AD) is a slowly progressive neurological disorder in which neurodegeneration is believed to begin 20-30 years before clinical onset [1]. Late-onset AD (LOAD) is clinically characterized by a progressive decline in memory and other cognitive functions, leading to the loss of the ability to perform everyday activities [2]. AD's clinical expression correlates with synaptic damage accompanied by neuronal loss in the brain, particularly in the hippocampus and cerebral cortex [3-6]. The mainstay of the therapy approved to treat AD dementia is based on only a few drugs, cholinesterase inhibitors (ChEIs), that act by increasing neurotransmitters' availability at synapses in the brain [7-12]. The therapy treats the final symptoms but does not prevent the underlying cause of the disease. The are many hypotheses regarding the primary cause of AD, including 
cholinergic neuron damage, the accumulation of proteins such as amyloid- $\beta(A \beta)$ in plaques, hyperphosphorylated-tau in neurofibrillary tangles leading to massive loss of synapses, inflammation, the role of butyrylcholinesterase (BChE) in forming $\mathrm{A} \beta$ plaques, and oxidative stress. By definition, age is the most potent risk factor for LOAD [13-16].

However, the disease seems to be multifactorial, with environmental and genetic factors contributing to disease risk, manifestation, and progression [17]. The results from genome-wide association studies (GWAS) have shown that the $\varepsilon 4$ allele of APOE is the most potent genetic risk factor for LOAD [18-22], followed by recently detected genetic risk factors that encode proteins involved in microglial function and inflammation, including triggering receptor expressed on myeloid cells-2 (TREM2) [23,24]. Many studies have shown that an imbalance between the production and clearance of amyloid- $\beta$ (A $\beta$ ) forming amyloid plaques is probably a significant contributor to neurodegeneration and disease development [25]. TREM2, present on the microglia cell membrane, interacts with apolipoprotein $\mathrm{E}(\mathrm{ApoE})$ and clusterin (CLU), leading to the internalization of apolipoproteins linked with $A \beta$ [26-28]. Apolipoprotein $\mathrm{E}$ (ApoE) is a protein mostly produced by astrocytes and microglia, and its function is to distribute cholesterol and lipids to neurons through binding to cell-surface ApoE receptors [29]. Additionally, ApoE forms complexes with $A \beta$ and plays a role in the clearance and metabolism of $A \beta$ [30]. The lipidation of ApoE and CLU enhances the eliminated A $\beta$ process. ApoE $\varepsilon 4$ indicates reduced lipidated status compared to other allelic forms, leading to ineffective clearance [26,31]. ApoE influences the propensity of $A \beta$ to aggregate into fibrillar plaques, affecting the rate of $A \beta$ clearance from the brain and the rate of conversion of $A \beta$ monomers and oligomers to mature fibrils, as well as the influence on microglial activation [32,33].

$\mathrm{A} \beta$ refers to peptides derived from the amyloid precursor protein (APP) that vary in length from 36 to 43 amino acids and are a major component of the amyloid plaques found in AD brains [34-36]. $A \beta 40$ is the most common, but $A \beta 42$ is more fibrillogenic and thus more associated with $\mathrm{AD}$ [37-39]. It has been proposed that the neurotoxicity of the $A \beta 42$ is linked to its aggregation state and interactions with metal ions such as iron, aluminum, copper, and zinc, which could play a crucial role in the release of reactive oxygen species (ROS) $[36,40,41]$. Accumulation of $A \beta$ plaques is thought to initiate a pathogenic cascade that leads to synaptic dysfunction and neurodegeneration $[42,43]$.

\section{Neuroinflammation in AD}

Postmortem analyses revealed that proteinopathy of AD caused by abnormal A $\beta$ aggregation is observed in 30-40\% of cognitively normal individuals [44-47]. However, only subjects with a build-up of both $A \beta$ plaques and high iron levels are likely to develop dementia. It has been proposed that high iron levels trigger an avalanche of events that push the progress of the disease, accelerating cognitive decline [48]. Iron is significantly elevated in multiple cortical regions of AD brains, and its accumulation may cause neuronal loss, possibly by inducing oxidative stress and neurodegeneration by ferroptosis [49,50].

Iron serves as a cofactor in several biological processes, including transport of oxygen, electron transfer in cytochromes, ATP synthesis, regulation of protein expression cell growth, and differentiation [51,52]. Moreover, iron is involved in the synthesis of neurotransmitters and myelination, and it is bound in iron-sulfur clusters that are required for many enzymes in the brain. The brain is one of the most metabolically active organs in the body, and an adequate supply of iron is essential to meet its high energy requirements [53].

The pleiotropic function of iron comes from its ability to reverse transition between its two oxidation states, ferrous $\left(\mathrm{Fe}^{2+}\right)$ and ferric $\left(\mathrm{Fe}^{3+}\right)$. However, ferrous ions can react with a product of mitochondrial respiration, hydrogen peroxide, to generate hydroxyl free radicals in the Fenton reaction. Subsequently, free radicals increase ROS production and enhance oxidative stress, promoting lipid peroxidation that can induce cell death by a pathway, ferroptosis, and thus neurodegeneration. Iron is a toxic trace element. Therefore, it has to be circulated throughout the body, attached to its carrier proteins or chelators involved in iron uptake, storage, and export in peripheral tissues [54-57]. 
Ferroptosis is a type of programmed cell death that involves iron dysregulation, lipid peroxidation, and inflammation. Ferroptosis is initiated by depletion of glutathione peroxidase (GPX4), resulting in an accumulation of lipid ROS in cells, leading to oxidative cell death. Interestingly, GPX4 knock-out in mice revealed not only iron dysregulation, lipid peroxidation, and inflammation, but also signs of $\mathrm{AD}$ and neurodegeneration $[49,58]$.

It has been hypothesized that brain iron elevation occurs after the formation of $A \beta$ plaques and neurofibrillary tangles (NFTs), and iron accumulation causes toxicity and neurodegeneration by inducing oxidative stress or cell death via ferroptosis [59]. How brain iron can trigger neurodegeneration remains incompletely understood. Here, we describe the known mechanisms involved in neuroinflammatory processes in the brain, with the focus on iron and AD.

Dietary iron absorbed by the gut enterocytes is transported throughout the body in blood plasma, bound to the iron carrier protein transferrin (Tf) as Tf-bound iron (TBI) [60]. Usually, only $30 \%$ of Tf proteins carry iron, which gives a large buffering capacity in case of increment in iron plasma concentration. TBI circulating in the blood cannot enter the brain directly, and the transport is controlled in a multistep transcellular pathway by the blood-brain barrier (BBB). The BBB is formed by brain microvascular endothelial cells (BMVECs), astrocytes, and pericytes, forming tight junctions. Most brain iron is acquired by Tf receptor (TFR-1)-mediated endocytosis at the lumen BMVECs of brain capillaries [61,62]. When the acidic $\mathrm{pH}$ is reached in endosomes, iron is released from $\mathrm{Tf}$, and endosomal ferri-reductase catalyzes the reduction of $\mathrm{Fe}^{3+}$ to $\mathrm{Fe}^{2+}$, enabling $\mathrm{Fe}^{2+}$ export into the cytosol from the endosome through divalent metal transporter-1 (DMT1) [63].

After crossing into the cytosol of the BMVEC, iron can be utilized in metabolic pathways, stored in the cytosolic and mitochondrial ferritin, or exported to the interstitial fluid in the brain via ferroportin (FPN) [64]. Ferritin is the cytosolic storage protein used to sequester iron in cells, keeping iron in a soluble, nontoxic but bioavailable form [65-67]. Both forms of iron, non-Tf-bound iron (NTBI) and TBI, have been identified in the brain interstitial fluid. However, NTBI is considered to be a physiologic form of iron, and the amount of TBI in the brain is thought to be 100 times less than levels circulating in plasma, whereas NTBI levels are high [68-70].

The brain comprises neurons and glial cells that include oligodendrocytes, astrocytes, ependymal cells, and microglia. These cells can uptake both Tf-bound and non-Tf-bound iron via two distinct pathways, via DMT- 1 and TFR-1 receptors, from the interstitial fluid. Oligodendrocytes only acquire non-Tf-bound iron via the Tim-1 receptor [71-74]. Iron can only be exported by these cells through FPN, a receptor controlled by hepcidin [61,64].

One evident hallmark of neuroinflammation is the cells' activation and increased acquisition of extracellular iron, causing the intracellular sequestration of iron in response to exogenous and endogenous danger signals. Such iron withdrawal plays a role in the brain to reduce the iron availability for bacteria, malignancies, and the endogenously produced ROS [75-79].

Microglia, which firstly respond to dangerous stimuli, are very long-lived myeloid immune cells of the central nervous system (CNS) (brain-resident macrophages), comprising up to $20 \%$ of the total brain glial cells. Their primary function is to search for and respond to danger signals by activation. M1 activation is proinflammatory and neurotoxic in response to the bacterial lipopolysaccharides, A $\beta$, interleukin 1 (IL-1), and ROS [80-85]. M1-activated microglia cells secrete proinflammatory cytokines such as tumor necrosis factor-alpha (TNF- $\alpha$ ), interleukin-6 (IL-6), interleukin-1-beta (IL-1 $\beta)$, and interleukin-12 (IL-12) [86]. Microglia in the M1 state also produce nitric oxide synthase (iNOS), which produces nitric oxide that increases the toxic effects of glutamate and consequently potentiates $\mathrm{N}$-methyl-D-aspartate (NMDA)-receptor-mediated neurotoxicity [87-89]. In the anti-inflammatory M2 state induced by interleukin-4 (IL-4) and interleukin-13 (IL-13), cells secrete anti-inflammatory cytokines such as interleukin-10 (IL-10) and transforming growth factor-beta (TGF- $\beta$ ). Danger signals, such as LPS, induce intracellular iron sequestration in cytosolic and mitochondrial ferritin in microglia and astrocytes to hide it from 
pathogens [90,91]. However, excess cytosolic iron can generate excessive ROS and the risk of microglial activation and inflammation of inflammasomes. NLRP3 inflammasomes are cytosolic multiprotein complexes abundantly expressed by microglia and astrocytes in response to dangerous stimuli like LPS, amyloid- $\beta$, iron-damaged mitochondria, and ROS [83]. The M1 state of microglia is activated by the NLRP3 inflammasome assembly with caspase- 1 and triggers the release of IL-1 $\beta$ and IL-18 [92].

M1-activated microglia, by secreting Il- $1 \alpha, \mathrm{TNF}$, and $\mathrm{C} 1 \mathrm{q}$, convert trophic astrocytes to a reactive subtype, termed A1. Together, these cytokines are necessary and sufficient to alter astrocytic transcriptomes, inducing the neurotoxic A1 cells to kill healthy neurons and oligodendrocytes [93-95]. Nonactivated astrocytes are essential for CNS and perform many functions, including maintenance of extracellular ion balance; biochemical support of BMVECs; and regulation of homeostasis, metabolism, and synaptic transmission. Growing evidence reports the significant role of A1 astrocytes in various human neurodegenerative diseases, including Alzheimer's, Huntington's, and Parkinson's diseases and multiple sclerosis. A1 astrocytes localize to A $\beta$ plaques in AD. Astrocytes are the most abundant glial cells in the CNS and play a critical role in neuroinflammation and produce chemokines and cytokines, including interleukin-1-beta (IL-1 $\beta$ ) and interleukin-6 (IL-6) [96]. Additionally, astrocytes also produce butyrylcholinesterase (BChE), the increased expression of which strongly correlates with the activation of astrocytes [97,98] (Figure 1).

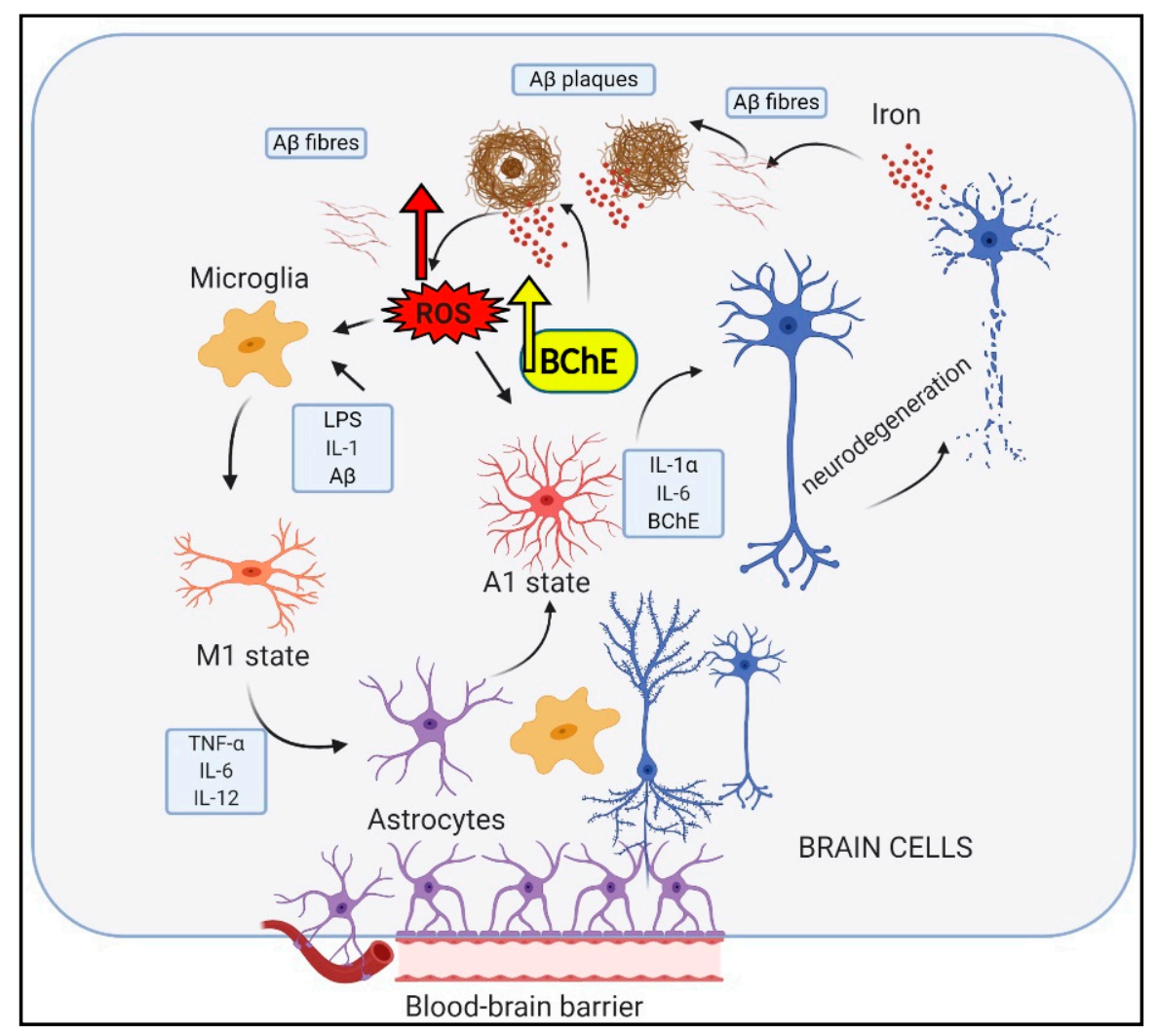

Figure 1. Neuroinflammation scheme. Danger signals, like reactive oxygen species (ROS) and LPS, are microglia activators and induce intracellular iron sequestration. LPS stimulates astrocytic hepcidin synthesis, which prevents iron efflux. LPS inhibits TREM-2 expressed on microglial cells, lowering $\mathrm{AB}$ clearance. Intracellular iron is bound to cellular ferritin but can dissociate and, via ROS, activate NLRP3 inflammasome, which triggers inflammation and microglial activation, M1 state. M1 microglial release of TNF- $\alpha, \mathrm{IL}-1 \alpha$, and C1q, which induce the phagocytosis of neurons and oligodendrocytes by A1 astrocytes, contributing to neurodegeneration and Alzheimer's disease (AD). A1 astrocytes produce IL- $1 \alpha$, IL-6, and BChE. 


\section{Brain Iron and Aging}

The concentration of iron varies significantly in different parts of the brain. Deposition of iron in the brain is positively correlated with age, with high concentrations in the frontal cortex, substantia nigra, basal ganglia, and hippocampus [99]. More iron is observed at the cellular level as a function of age in the microglia and astrocytes of the cortex, cerebellum, hippocampus, basal ganglia, and amygdala, which are particularly susceptible to the neuropathological changes that characterize AD [100-102]. Iron accumulation can stimulate the activation of these cells in the neuroinflammatory processes that contribute to AD. Iron levels in the brain rise with aging, and excess active iron can be toxic through various mechanisms, including oxidative stress and the promotion of lipid peroxidation that can induce cell death by a regulated cell death pathway, ferroptosis $[49,58,103]$. Even a delicate imbalance in brain iron is likely to have an adverse effect because, unlike serum transferrin (Tf), which is only $30-40 \%$ saturated with iron, brain Tf is $100 \%$ saturated and has a limited capacity for buffering excess iron $[53,104,105]$.

\section{Regulation of Iron Homeostasis}

Iron enters brain cells mainly via DMT- 1 and TFR-1 [62,106,107]. Its metabolism is controlled by two regulatory systems, one that relies on the iron exporter FPN and its regulator, hepcidin, and the second that controls cellular iron levels through iron-regulatory proteins that bind iron-responsive elements in regulated messenger RNAs [108].

Hepcidin is a peptide hormone produced by hepatocytes, but only a small fraction of this peptide hormone crosses the blood-brain barrier (BBB) $[79,109]$. The brain biosynthesizes its own hepcidin by astrocytes and microglia in response to LPS and proinflammatory cytokines via the IL-6/STAT3 and SMAD4 pathways [110,111]. Hepcidin in the extracellular space inhibits iron export by binding to FPN and mediates FPN internalization and degradation in lysosomes [64]. In the CNS, iron sequestration by hepcidin may be beneficial and neuroprotective as it denies iron to pathogens, limiting infection and inflammation [79]. On the other hand, aging enhances the expression of hepcidin and LCN-2, increases the concentration of intracellular iron, and promotes inflammation via NLRP3 inflammasomes $[84,112,113]$. It seems that hepcidin brain secretion may have both beneficial and detrimental effects, depending on the cause of inflammation.

Iron efflux via FPN is also controlled by APP $[114,115]$. APP is a transmembrane glycoprotein that plays many roles in the nervous system, including neuronal development, signaling, intracellular transport, maintenance of dendritic structure, and regulation of synapses [34,116-119]. Non-amyloidogenic $\alpha$-secretase processing of APP generates $\operatorname{sAPP} \alpha$, which binds to FPN on the cell surface and stabilizes it, thus promoting neuronal iron efflux and decreased intraneuronal iron. On the other hand, amyloidogenic processing of APP impairs iron export by depleting FPN on the cell surface, thus increasing cellular iron that induces neurodegeneration. It is proposed that in this way, $\beta$-secretase processing of APP might indirectly promote ferroptosis [120-122]. Strikingly, a transgenic mouse model that has abundant $A \beta$ deposition is not sufficient for synapse loss. However, $\beta$-secretase cleavage of APP by itself has been reported to cause synaptic and memory deficits [123].

Cellular iron homeostasis involves the coordination of iron uptake, storage, and efflux to ensure appropriate iron levels inside the cell and is controlled by the second mechanism at the post-transcriptional level. Brain iron homeostasis is regulated by a posttranscriptional gene expression regulation system composed of iron-regulatory proteins (IRPs), IRP1 and IRP2 and iron-responsive elements (IREs) that are present in mRNAs encoding for essential proteins of iron homeostasis. IREs are conserved mRNA motifs of 25-30 nucleotides located in the untranslated regions (UTRs) of mRNAs that can form a stem-loop [124]. Under high-cellular-iron conditions, the IRPs cannot bind the IREs because IRP1 assembles an iron-sulfur cluster, and it acts as a cytosolic aconitase, while IRP2 is degraded by the proteosome. Therefore, IRPs become IRE-binding proteins only in low concentrations of iron. Depending on the IRE position in the untranslated regions 
(UTRs) of mRNA, IRP binding regulates gene expression differentially. IRPs bound to IREs at the $5^{\prime}$ UTR of mRNA inhibit translation initiation by preventing the recruitment of the small ribosomal subunit to the mRNA. The IRPs bound to IREs at the $3^{\prime}$ UTR of mRNA decrease their turnover by preventing endonucleolytic cleavage and mRNA degradation. The IRP mRNA stabilization mechanism has not been fully understood yet for all 3'IRE-containing mRNAs, such as DMT1, which only has a single 3'IRE and may require additional regulation factors $[63,108,125]$. In the case of a high iron concentration in cells, IRPs bind to the IRE of TFR1 and DMT1 mRNAs, decreasing their translation and resulting in lower cellular uptake of iron. In the opposite situation, when cellular iron levels are low, IRPs bind to the IRE at the $3^{\prime}$-UTR of TFR1 and DMT1 mRNAs, stabilizing them, increasing their cellular expression level, and thus increasing iron uptake. IRP-IRE interactions regulate the expression of the mRNAs encoding essential proteins for iron homeostasis, such as transferrin receptor 1 (TFR1), divalent metal transporter 1 (DMT-1), H-ferritin (Fth1), L-ferritin (Ftl), mitochondrial aconitase (Aco2), and ferroportin (FPN) [126].

Under low-iron conditions, IRP1 also binds to the IRE at the $5^{\prime}$-UTR of APP mRNA to repress APP translation $[127,128]$. A high iron load upregulates APP translation and increases the amyloidogenic processing of APP that generates A $\beta$ peptide [85]. Monomeric $\mathrm{A} \beta$ reduces oxidative stress, inhibits $\mathrm{Fe}^{3+}$ reduction, and prevents lipid peroxidation and ferroptosis induced by $\mathrm{Fe}^{2+}$ [129-131].

\section{Butyrylcholinesterase in AD}

Butyrylcholinesterase (UniProt P06276), also known as plasma cholinesterase or pseudocholinesterase, is a serine hydrolase present in most tissues, with the highest levels in plasma and the liver [132]. Although the enzyme $\mathrm{BChE}$ and its coding gene were discovered years ago, still little is known about the regulation of the expression and its biological role, particularly in the central nervous system (CNS) $[133,134]$. BChE is expressed during mitosis in early embryonic development and promotes proliferation prior to differentiation [135].

$\mathrm{BChE}$ has a widespread distribution in the human body, and it serves as an inherent protector from damage caused by toxic compounds before they reach acetylcholinesterase (AChE) in synapses. BChE is found in glia and white matter in the brain, and it is involved, along with AChE, in cholinergic neurotransmission $[136,137]$. In the human brain, BChE is mainly expressed in glial cells, particularly astrocytes, in contrast to AChE, which is found in neurons. Nevertheless, BChE is also found in specific neurons, mainly localized in the amygdala, hippocampus, and thalamus $[138,139]$. The primary source of $\mathrm{BChE}$ in the CNS is non-neuron cells such as astrocytes and microglia, which also express nicotinic acetylcholine $(\mathrm{ACh})$ receptors, indicating that $\mathrm{BChE}$ might play a regulatory role in the functional status of these cells via its ACh-hydrolyzing activity [140]. BChE was found in amyloid plaques and neurofibrillary tangles (NFTs), suggesting that the protein may be involved in AD's pathogenesis [141-145]. Other researchers demonstrated that BChE might transform $A \beta$ from an initially benign to an eventually malignant form [146].

Interestingly, mRNA sequence analysis revealed putative IRE in $3^{\prime}$-UTR of BChE (at low quality) (Figure 2), suggesting that $\mathrm{BChE}$ can also be regulated by iron homeostasis. Under low iron concentration, IRP1/IRP2 proteins probably bind to stem-loop in 3'-UTR of $\mathrm{BChE}$ transcript and stabilize it by preventing degradation, thus increasing the $\mathrm{BChE}$ expression level. To support this hypothesis, we found a strong correlation between BChE activity and the red blood cell (RBC) count in a large cohort of 1200 individuals (not published previously, found the correlation of the old data) [147]. We observed that the level of the BChE activity is proportional to the RBC count (Figure 3). Since RBCs bind $65 \%$ of body iron, it seems that the $\mathrm{BChE}$ level is proportional to the body iron level [148]. The lifetime of RBCs is about 100-120 days, and the aging RBCs undergo eryptosis, programmed death. Much of the breakdown products are recirculated by the spleen and the liver. The iron is released into the plasma to be recirculated by Tf. Thus, the recirculated TBI is proportional to the RBC count. Since that the liver mainly produces 
serum BChE, the biosynthesis may be regulated similarly to TFR1 by IRPs. On the other hand, iron upregulates erythropoiesis levels by enhancing erythropoietin (EPO) synthesis by transcriptional activation. HIF- $2 \alpha$ mediates the EPO gene's transcriptional activation by binding to its hypoxia response element (HRE). Iron excess prevents binding of IRP1 to the IRE sequence at $5^{\prime}$-UTR of the HIF- $2 \alpha$ and leads to prolonged translation of HIF- $2 \alpha$ and thus increases the level of EPO [149-153]. Taken together, the BChE and the RBC levels can similarly reflect the concentration of cellular iron or TBI.

Strikingly, increased $\mathrm{BChE}$ activity is associated with $\mathrm{A} 1$ astrocytes in the $\mathrm{AD}$ brain. The expression of $\mathrm{BChE}$ is also increased in the hippocampus and temporal cortex of patients with $\mathrm{AD}$, whereas the expression of $\mathrm{AChE}$ is reduced.

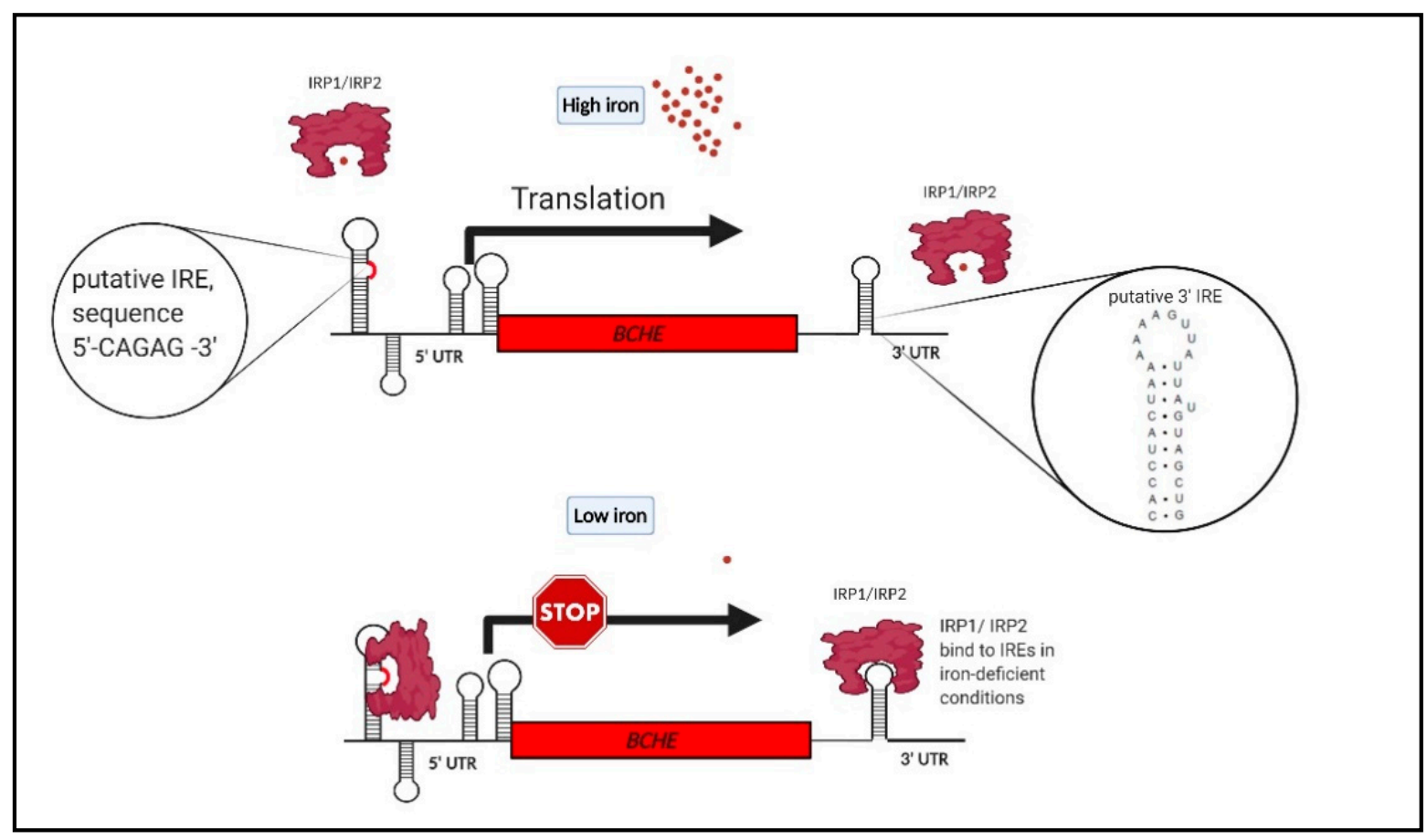

Figure 2. Proposed model of BChE expression regulation by iron in the activated glial cells. mRNA sequence analysis revealed putative IRE in the $3^{\prime}$-UTR of BChE (at low quality) and in the $5^{\prime}$-UTR. The Searching for IREs (SIREs) web bioinformatic program was used to predict the $3^{\prime}$-UTR iron-responsive elements in BCHE mRNA [154]. In 5'-UTR, only the consensus IRP binding sequence was found; however, since the expected structure of the $5^{\prime}$-UTR is complex [155], a stem-loop can be formed in a controlled process. Under conditions of high cellular iron, the IRPs cannot bind the IREs. IREs are conserved mRNA motifs. IRPs bound to IREs at the $5^{\prime}$-UTR of mRNA inhibit translation initiation by preventing ribosome binding to the mRNA. The IRPs bound to IREs at the $3^{\prime}$-UTR of mRNA decrease its turnover by preventing endonucleolytic cleavage and mRNA degradation. We suppose that the BChE expression can be positively regulated by iron in the $5^{\prime}$-UTR IRE element and in $3^{\prime}$-UTR by one stem-loop with additional regulator factors as a negative feedback mechanism. In order to validate the predicted IREs, the in vitro functionality has to be determined by competitive EMSA experiments. 


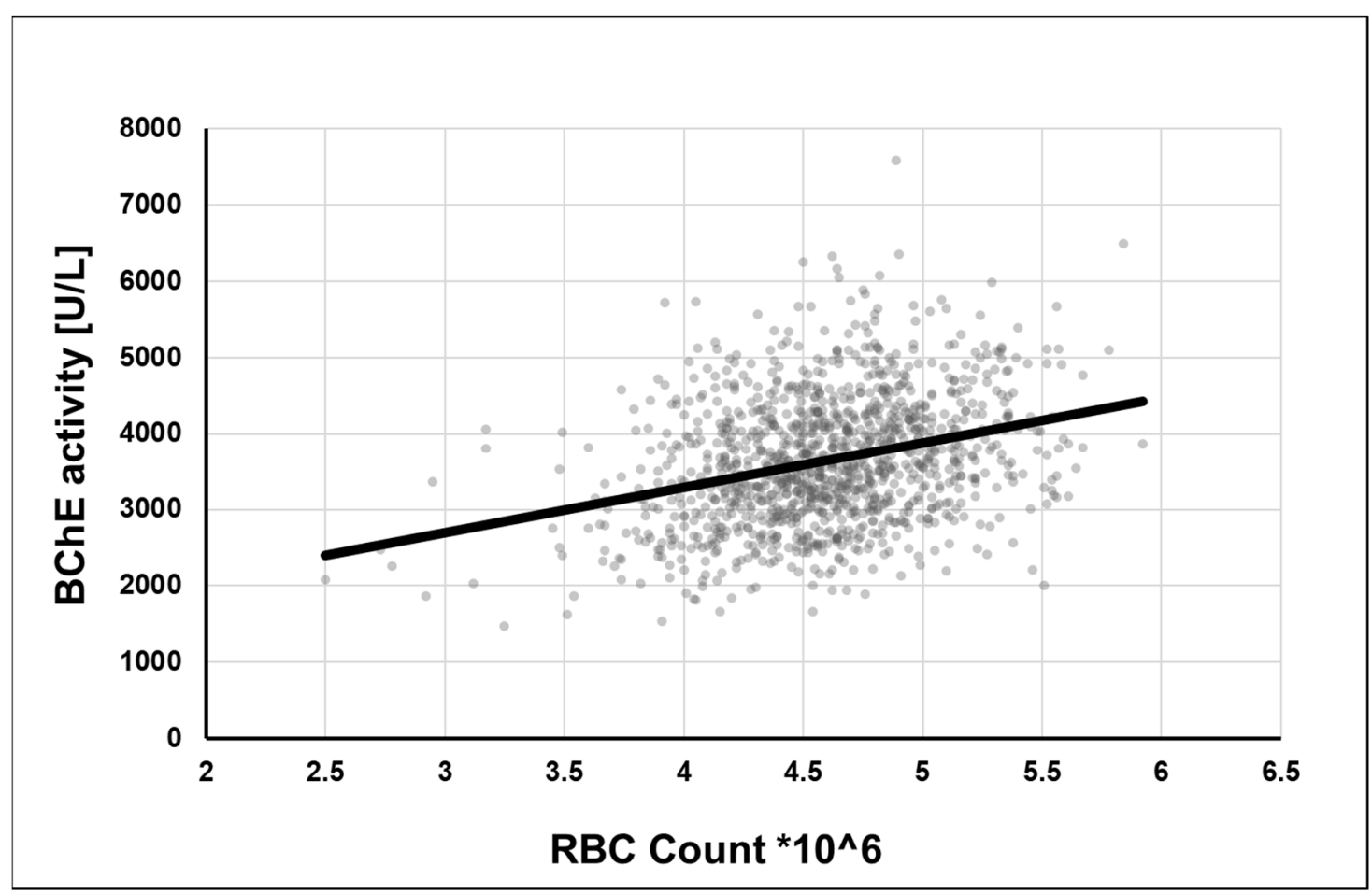

Figure 3. Interrelationship of peripheral serum butyrylcholinesterase (BChE) activity and red blood cell (RBC) count. The plasma BChE level shows a positive correlation with RBC count in a large cohort of 1191 individuals. The enzyme activity of a single person is represented by a grey dot. BChE activity was measured by Ellman's reaction, as described earlier [156].

\section{Conclusions}

Iron homeostasis becomes dysregulated during aging, leading to iron overload, which may promote neuroinflammation, protein aggregation, neurodegeneration, and AD development. Therefore, iron chelation and iron-targeted therapeutic strategies have been proposed as potential therapeutic strategies for neurodegenerative diseases [157]. Indeed, the anti-inflammatory iron chelator deferiprone is currently in phase 2 trials for $\mathrm{AD}$ and could soon become an FDA-approved iron chelator recommended for AD therapy [158]. Interestingly, conjugation of a cholinesterase inhibitor, such as galantamine, with the natural iron chelator lactoferrin was suggested as an AD therapy. Administration of iron chelates, like deferoxamine (DFO), significantly reverses changes due to iron overload. It has been shown that DFO inhibits $A \beta$ toxicity via the modulation of $A \beta$-metal interactions, inhibits amyloidogenic APP processing, reduces the formation of ROS, and decreases $A \beta$ oligomerization. DFO and other prospective metal chelators are promising drug candidates for managing neurodegeneration in the aging population [159-161].

Protein aggregation, neuroinflammation, and neuronal loss that lead to cognitive dysfunctions are neuropathological hallmarks of $\mathrm{AD}$, and age-related iron dyshomeostasis can play a leading role in the processes. $\mathrm{BChE}$ produced by glial cells in response to proinflammatory signals and iron-dependent elevated levels of the BChE can make AD patients' cognitive situation worse by accelerating acetylcholine decay in aging brains.

Author Contributions: Conceptualization, J.J. and M.T.; software, J.J.; formal analysis, J.J.; writingoriginal draft preparation, J.J.; writing—review and editing, J.J., M.T. and B.W.; visualization, J.J.; supervision, J.J.; project administration, J.J.; funding acquisition, J.J. and B.W. All authors have read and agreed to the published version of the manuscript.

Funding: This work was supported by the Ministry of Science and Higher Education Republic of Poland from the quality-promoting subsidy under the Leading National Research Centre (KNOW) program 2012-2017 Faculty of Pharmacy with Subfaculty of Laboratory Medicine [dec. MNiSW-DS6002-4693-23/WA/12]. 
Institutional Review Board Statement: Not applicable.

Informed Consent Statement: Not applicable.

Data Availability Statement: Not applicable.

Acknowledgments: Figures 1 and 2 were created with BioRender.com.

Conflicts of Interest: The authors declare no conflict of interest.

\section{References}

1. Scheltens, P.; Blennow, K.; Breteler, M.M.B.; de Strooper, B.; Frisoni, G.B.; Salloway, S.; Van der Flier, W.M. Alzheimer's disease. Lancet 2016, 388, 505-517. [CrossRef]

2. Gold, C.A.; Budson, A.E. Memory loss in Alzheimer's disease: Implications for development of therapeutics. Expert Rev. Neurother. 2008, 8, 1879-1891. [CrossRef] [PubMed]

3. Davies, P. Selective loss of central cholinergic neurons in Alzheimer's disease. Lancet 1976, 308, 1403. [CrossRef]

4. Ball, M.J. Neuronal loss, neurofibrillary tangles and granulovacuolar degeneration in the hippocampus with ageing and dementia. Acta Neuropathol. 1977, 37, 111-118. [CrossRef]

5. Serrano-Pozo, A.; Frosch, M.P.; Masliah, E.; Hyman, B.T. Neuropathological Alterations in Alzheimer Disease. Cold Spring Harb. Perspect. Med. 2011, 1, 1-23. [CrossRef] [PubMed]

6. West, M.; Coleman, P.; Flood, D.; Troncoso, J. Differences in the pattern of hippocampal neuronal loss in normal ageing and Alzheimer's disease. Lancet 1994, 344, 769-772. [CrossRef]

7. Lane, R.M.; Potkin, S.G.; Enz, A. Targeting acetylcholinesterase and butyrylcholinesterase in dementia. Int. J. Neuropsychopharmacol. 2005, 9, 101-124. [CrossRef]

8. Szeto, J.Y.Y.; Lewis, S.J.G. Current Treatment Options for Alzheimer's Disease and Parkinson's Disease Dementia. Curr. Neuropharmacol. 2016, 14, 326-338. [CrossRef]

9. Grutzendler, J.; Morris, J.C. Cholinesterase Inhibitors for Alzheimer's disease. Drugs 2001, 61, 41-52. [CrossRef]

10. Haam, J.; Yakel, J.L. Cholinergic modulation of the hippocampal region and memory function. J. Neurochem. 2017, 142, 111-121. [CrossRef]

11. Lee, J.-H.; Jeong, S.-K.; Kim, B.C.; Park, K.W.; Dash, A. Donepezil across the spectrum of Alzheimer's disease: Dose optimization and clinical relevance. Acta Neurol. Scand. 2015, 131, 259-267. [CrossRef] [PubMed]

12. Bergmann, K.; Tomlinson, B.E.; Blessed, G.; Gibson, P.H.; Perry, R.H. Correlation of cholinergic abnormalities with senile plaques and mental test scores in senile dementia. Br. Med. J. 1978, 2, 1457-1459.

13. Hyman, B.T.; Trojanowski, J.Q. Editorial on Consensus Recommendations for the Postmortem Diagnosis of Alzheimer Disease from the National Institute on Aging and the Reagan Institute Working Group on Diagnostic Criteria for the Neuropathological Assessment of Alzheimer Disease. J. Neuropathol. Exp. Neurol. 1997, 56, 1095-1097. [CrossRef]

14. Whitehouse, P.J.; Price, D.L.; Struble, R.G.; Clark, A.W.; Coyle, J.T.; DeLong, M.R. Alzheimer's disease and senile dementia: Loss of neurons in the basal forebrain. Science 1982, 215, 1237-1239. [CrossRef]

15. Ballatore, C.; Lee, V.M.Y.; Trojanowski, J.Q. Tau-mediated neurodegeneration in Alzheimer's disease and related disorders. Nat. Rev. Neurosci. 2007, 8, 663-672. [CrossRef] [PubMed]

16. Hebert, L.E. Age-Specific Incidence of Alzheimer's Disease in a Community Population. JAMA J. Am. Med. Assoc. 1995, 273, 1354-1359. [CrossRef]

17. Buxbaum, J.N. Alzheimer's Disease: It's More Than A $\beta$. FASEB J. 2017, 31, 2-4. [CrossRef] [PubMed]

18. Jun, G. Meta-analysis Confirms CR1, CLU, and PICALM as Alzheimer Disease Risk Loci and Reveals Interactions with APOE Genotypes. Arch. Neurol. 2010, 67, 1473-1484. [CrossRef]

19. Lambert, J.-C.; Heath, S.; Even, G.; Campion, D.; Sleegers, K.; Hiltunen, M.; Combarros, O.; Zelenika, D.; Bullido, M.J.; Tavernier, B.; et al. Genome-wide association study identifies variants at CLU and CR1 associated with Alzheimer's disease. Nat. Genet. 2009, 41, 1094-1099. [CrossRef]

20. Corder, E.; Saunders, A.; Strittmatter, W.; Schmechel, D.; Gaskell, P.; Small, G.; Roses, A.; Haines, J.; Pericak-Vance, M. Gene dose of apolipoprotein E type 4 allele and the risk of Alzheimer's disease in late onset families. Science 1993, 261, 921-923. [CrossRef]

21. Seshadri, S. Genome-wide Analysis of Genetic Loci Associated with Alzheimer Disease. JAMA 2010, 303, 1832-1840. [CrossRef] [PubMed]

22. Lucotte, G.; Visvikis, S.; Leininger-Möler, B.; David, F.; Berriche, S.; Revéilleau, S.; Couderc, R.; Babron, M.C.; Aguillon, D.; Siest, G. Association of apolipoprotein E allele $\varepsilon 4$ with late-onset sporadic Alzheimer's disease. Am. J. Med. Genet. 1994, 54, $286-288$. [CrossRef]

23. Malik, M.; Parikh, I.; Vasquez, J.B.; Smith, C.; Tai, L.; Bu, G.; LaDu, M.J.; Fardo, D.W.; Rebeck, G.W.; Estus, S. Genetics ignite focus on microglial inflammation in Alzheimer's disease. Mol. Neurodegener. 2015, 10, 52-64. [CrossRef]

24. Gratuze, M.; Leyns, C.E.G.; Holtzman, D.M. New insights into the role of TREM2 in Alzheimer's disease. Mol. Neurodegener. 2018, 13, 66-82. [CrossRef] [PubMed] 
25. Christie, R.H.; Bacskai, B.J.; Zipfel, W.R.; Williams, R.M.; Kajdasz, S.T.; Webb, W.W.; Hyman, B.T. Growth Arrest of Individual Senile Plaques in a Model of Alzheimer's Disease Observed by In Vivo Multiphoton Microscopy. J. Neurosci. 2001, 21, 858-864. [CrossRef]

26. Yeh, F.L.; Wang, Y.; Tom, I.; Gonzalez, L.C.; Sheng, M. TREM2 Binds to Apolipoproteins, Including APOE and CLU/APOJ, and Thereby Facilitates Uptake of Amyloid-Beta by Microglia. Neuron 2016, 91, 328-340. [CrossRef] [PubMed]

27. DeMattos, R.B.; Cirrito, J.R.; Parsadanian, M.; May, P.C.; O’Dell, M.A.; Taylor, J.W.; Harmony, J.A.K.; Aronow, B.J.; Bales, K.R.; Paul, S.M.; et al. ApoE and Clusterin Cooperatively Suppress A $\beta$ Levels and Deposition: Evidence that ApoE Regulates Extracellular A $\beta$ Metabolism In Vivo. Neuron 2004, 41, 193-202. [CrossRef]

28. Foster, E.M.; Dangla-Valls, A.; Lovestone, S.; Ribe, E.M.; Buckley, N.J. Clusterin in Alzheimer's disease: Mechanisms, genetics, and lessons from other pathologies. Front. Neurosci. 2019, 13, 1-27. [CrossRef]

29. Yamazaki, Y.; Zhao, N.; Caulfield, T.R.; Liu, C.-C.; Bu, G. Apolipoprotein E and Alzheimer disease: Pathobiology and targeting strategies. Nat. Rev. Neurol. 2019, 15, 501-518. [CrossRef]

30. Kumar, R.; Nordberg, A.; Darreh-Shori, T. Amyloid- $\beta$ peptides act as allosteric modulators of cholinergic signalling through formation of soluble BA $\beta$ ACs. Brain 2016, 139, 174-192. [CrossRef]

31. Zhao, J.; Davis, M.D.; Martens, Y.A.; Shinohara, M.; Graff-Radford, N.R.; Younkin, S.G.; Wszolek, Z.K.; Kanekiyo, T.; Bu, G. APOE $\varepsilon 4 / \varepsilon 4$ diminishes neurotrophic function of human iPSC-derived astrocytes. Hum. Mol. Genet. 2017, 26, 2690-2700. [CrossRef]

32. Ulrich, J.D.; Ulland, T.K.; Mahan, T.E.; Nyström, S.; Nilsson, K.P.; Song, W.M.; Zhou, Y.; Reinartz, M.; Choi, S.; Jiang, H.; et al. ApoE facilitates the microglial response to amyloid plaque pathology. J. Exp. Med. 2018, 215, 1047-1058. [CrossRef] [PubMed]

33. Fernandez, C.G.; Hamby, M.E.; McReynolds, M.L.; Ray, W.J. The Role of APOE4 in Disrupting the Homeostatic Functions of Astrocytes and Microglia in Aging and Alzheimer's Disease. Front. Aging Neurosci. 2019, 11, 14-32. [CrossRef] [PubMed]

34. Zhang, T.; Chen, D.; Lee, T.H. Phosphorylation Signaling in APP Processing in Alzheimer's Disease. Int. J. Mol. Sci. 2019, 21, 209. [CrossRef]

35. Zhou, R.; Yang, G.; Guo, X.; Zhou, Q.; Lei, J.; Shi, Y. Recognition of the amyloid precursor protein by human $\gamma$-secretase. Science 2019, 363, eaaw0930. [CrossRef] [PubMed]

36. Chen, G.; Xu, T.; Yan, Y.; Zhou, Y.; Jiang, Y.; Melcher, K.; Xu, H.E. Amyloid beta: Structure, biology and structure-based therapeutic development. Acta Pharmacol. Sin. 2017, 38, 1205-1235. [CrossRef]

37. Demuro, A.; Mina, E.; Kayed, R.; Milton, S.C.; Parker, I.; Glabe, C.G. Calcium Dysregulation and Membrane Disruption as a Ubiquitous Neurotoxic Mechanism of Soluble Amyloid Oligomers. J. Biol. Chem. 2005, 280, 17294-17300. [CrossRef]

38. Prangkio, P.; Yusko, E.C.; Sept, D.; Yang, J.; Mayer, M. Multivariate Analyses of Amyloid-Beta Oligomer Populations Indicate a Connection between Pore Formation and Cytotoxicity. PLoS ONE 2012, 7, e47261. [CrossRef]

39. Pedersen, W.A.; Kloczewiak, M.A.; Blusztajn, J.K. Amyloid beta-protein reduces acetylcholine synthesis in a cell line derived from cholinergic neurons of the basal forebrain. Proc. Natl. Acad. Sci. USA 1996, 93, 8068-8071. [CrossRef]

40. Smith, M.A.; Zhu, X.; Tabaton, M.; Liu, G.; McKeel, D.W.; Cohen, M.L.; Wang, X.; Siedlak, S.L.; Dwyer, B.E.; Hayashi, T.; et al. Increased Iron and Free Radical Generation in Preclinical Alzheimer Disease and Mild Cognitive Impairment. J. Alzheimer's Dis. 2010, 19, 363-372. [CrossRef]

41. Maynard, C.J.; Cappai, R.; Volitakis, I.; Cherny, R.A.; White, A.R.; Beyreuther, K.; Masters, C.L.; Bush, A.I.; Li, Q.-X. Overexpression of Alzheimer's Disease Amyloid- $\beta$ Opposes the Age-dependent Elevations of Brain Copper and Iron. J. Biol. Chem. 2002, 277, 44670-44676. [CrossRef] [PubMed]

42. Archer, H.A.; Edison, P.; Brooks, D.J.; Barnes, J.; Frost, C.; Yeatman, T.; Fox, N.C.; Rossor, M.N. Amyloid load and cerebral atrophy in Alzheimer's disease: An 11 C-PIB positron emission tomography study. Ann. Neurol. 2006, 60, 145-147. [CrossRef]

43. Klunk, W.E.; Engler, H.; Nordberg, A.; Wang, Y.; Blomqvist, G.; Holt, D.P.; Bergström, M.; Savitcheva, I.; Huang, G.-F.; Estrada, S.; et al. Imaging brain amyloid in Alzheimer's disease with Pittsburgh Compound-B. Ann. Neurol. 2004, 55, 306-319. [CrossRef]

44. Bennett, D.A.; Schneider, J.A.; Arvanitakis, Z.; Kelly, J.F.; Aggarwal, N.T.; Shah, R.C.; Wilson, R.S. Neuropathology of older persons without cognitive impairment from two community-based studies. Neurology 2006, 66, 1837-1844. [CrossRef] [PubMed]

45. Aizenstein, H.J.; Nebes, R.D.; Saxton, J.A.; Price, J.C.; Mathis, C.A.; Tsopelas, N.D.; Ziolko, S.K.; James, J.A.; Snitz, B.E.; Houck, P.R.; et al. Frequent Amyloid Deposition without Significant Cognitive Impairment Among the Elderly. Arch. Neurol. 2008, 65, 1509-1517. [CrossRef] [PubMed]

46. Drachman, D.A. The amyloid hypothesis, time to move on: Amyloid is the downstream result, not cause, of Alzheimer's disease. Alzheimer's Dement. 2014, 10, 372-380. [CrossRef]

47. Jansen, W.J.; Ossenkoppele, R.; Knol, D.L.; Tijms, B.M.; Scheltens, P.; Verhey, F.R.J.; Visser, P.J.; Aalten, P.; Aarsland, D.; Alcolea, D.; et al. Prevalence of Cerebral Amyloid Pathology in Persons without Dementia. JAMA 2015, 313, 1924-1938. [CrossRef] [PubMed]

48. Ayton, S.; Wang, Y.; Diouf, I.; Schneider, J.A.; Brockman, J.; Morris, M.C.; Bush, A.I. Brain iron is associated with accelerated cognitive decline in people with Alzheimer pathology. Mol. Psychiatry 2020, 25, 2932-2941. [CrossRef]

49. Stockwell, B.R.; Friedmann Angeli, J.P.; Bayir, H.; Bush, A.I.; Conrad, M.; Dixon, S.J.; Fulda, S.; Gascón, S.; Hatzios, S.K.; Kagan, V.E.; et al. Ferroptosis: A Regulated Cell Death Nexus Linking Metabolism, Redox Biology, and Disease. Cell 2017, 171, $273-285$. [CrossRef]

50. Zecca, L.; Gallorini, M.; Schünemann, V.; Trautwein, A.X.; Gerlach, M.; Riederer, P.; Vezzoni, P.; Tampellini, D. Iron, neuromelanin and ferritin content in the substantia nigra of normal subjects at different ages: Consequences for iron storage and neurodegenerative processes. J. Neurochem. 2001, 76, 1766-1773. [CrossRef] 
51. Trinder, D.; Fox, C.; Vautier, G.; Olynyk, J.K. Molecular pathogenesis of iron overload. Gut 2002, 51, 290-295. [CrossRef] [PubMed]

52. Hentze, M.W.; Muckenthaler, M.U.; Galy, B.; Camaschella, C. Two to Tango: Regulation of Mammalian Iron Metabolism. Cell 2010, 142, 24-38. [CrossRef] [PubMed]

53. Nnah, I.; Wessling-Resnick, M. Brain Iron Homeostasis: A Focus on Microglial Iron. Pharmaceuticals 2018, 11, 129. [CrossRef] [PubMed]

54. Kruszewski, M. Labile iron pool: The main determinant of cellular response to oxidative stress. Mutat. Res. Fundam. Mol. Mech. Mutagenes. 2003, 531, 81-92. [CrossRef]

55. Halliwell, B. Oxidative stress and neurodegeneration: Where are we now? J. Neurochem. 2006, 97, 1634-1658. [CrossRef] [PubMed]

56. Crichton, R. Iron Metabolism; John Wiley \& Sons, Ltd.: Chichester, UK, 2016; ISBN 9781118925645.

57. Beard, J.L.; Connor, J.R. Iron status and neural functioning. Annu. Rev. Nutr. 2003, 23, 41-58. [CrossRef] [PubMed]

58. Dixon, S.J. Ferroptosis: Bug or feature? Immunol. Rev. 2017, 277, 150-157. [CrossRef] [PubMed]

59. Heneka, M.T.; Carson, M.J.; El Khoury, J.; Landreth, G.E.; Brosseron, F.; Feinstein, D.L.; Jacobs, A.H.; Wyss-Coray, T.; Vitorica, J.; Ransohoff, R.M.; et al. Neuroinflammation in Alzheimer's disease. Lancet Neurol. 2015, 14, 388-405. [CrossRef]

60. Steele, T.M.; Frazer, D.M.; Anderson, G.J. Systemic regulation of intestinal iron absorption. IUBMB Life 2005, 57, 499-503. [CrossRef] [PubMed]

61. Qian, Z.; Ke, Y. Brain iron transport. Biol. Rev. 2019, 94, 1672-1684. [CrossRef]

62. Duck, K.A.; Simpson, I.A.; Connor, J.R. Regulatory mechanisms for iron transport across the blood-brain barrier. Biochem. Biophys. Res. Commun. 2017, 494, 70-75. [CrossRef] [PubMed]

63. Yanatori, I.; Kishi, F. Free Radical Biology and Medicine DMT1 and iron transport. Free Radic. Biol. Med. 2019, 133, 55-63. [CrossRef]

64. Nemeth, E. Hepcidin Regulates Cellular Iron Efflux by Binding to Ferroportin and Inducing Its Internalization. Science 2004, 306, 2090-2093. [CrossRef] [PubMed]

65. Wang, W.; Knovich, M.A.; Coffman, L.G.; Torti, F.M.; Torti, S.V. Serum ferritin: Past, present and future. Biochim. Biophys. Acta Gen. Subj. 2010, 1800, 760-769. [CrossRef]

66. Arosio, P.; Elia, L.; Poli, M. Ferritin, cellular iron storage and regulation. IUBMB Life 2017, 69, 414-422. [CrossRef] [PubMed]

67. Watt, R.K. A Unified Model for Ferritin Iron Loading by the Catalytic Center: Implications for Controlling "Free Iron" during Oxidative Stress. ChemBioChem 2013, 14, 415-419. [CrossRef]

68. Moos, T.; Morgan, E.H. Evidence for low molecular weight, non-transferrin-bound iron in rat brain and cerebrospinal fluid. J. Neurosci. Res. 1998, 54, 486-494. [CrossRef]

69. Moos, T.; Nielsen, T.R.; Skjørringe, T.; Morgan, E.H. Iron trafficking inside the brain. J. Neurochem. 2007, 103, 1730-1740. [CrossRef]

70. Codazzi, F.; Pelizzoni, I.; Zacchetti, D.; Grohovaz, F. Iron entry in neurons and astrocytes: A link with synaptic activity. Front. Mol. Neurosci. 2015, 8, 18. [CrossRef] [PubMed]

71. Connor, J.R.; Menzies, S.L. Cellular management of iron in the brain. J. Neurol. Sci. 1995, 134, 33-44. [CrossRef]

72. Todorich, B.; Zhang, X.; Connor, J.R. H-ferritin is the major source of iron for oligodendrocytes. Glia 2011, 59, 927-935. [CrossRef]

73. Chen, T.T.; Li, L.; Chung, D.H.; Allen, C.D.C.; Torti, S.V.; Torti, F.M.; Cyster, J.G.; Chen, C.Y.; Brodsky, F.M.; Niemi, E.C.; et al. TIM-2 is expressed on B cells and in liver and kidney and is a receptor for H-ferritin endocytosis. J. Exp. Med. 2005, 202, 955-965. [CrossRef] [PubMed]

74. Chiou, B.; Lucassen, E.; Sather, M.; Kallianpur, A.; Connor, J. Semaphorin4A and H-ferritin utilize Tim-1 on human oligodendrocytes: A novel neuro-immune axis. Glia 2018, 66, 1317-1330. [CrossRef]

75. Abreu, R.; Quinn, F.; Giri, P.K. Role of the hepcidin-ferroportin axis in pathogen-mediated intracellular iron sequestration in human phagocytic cells. Blood Adv. 2018, 2, 1089-1100. [CrossRef]

76. Nemeth, E.; Valore, E.V.; Territo, M.; Schiller, G.; Lichtenstein, A.; Ganz, T. Hepcidin, a putative mediator of anemia of inflammation, is a type II acute-phase protein. Blood 2003, 101, 2461-2463. [CrossRef] [PubMed]

77. Nemeth, E.; Rivera, S.; Gabayan, V.; Keller, C.; Taudorf, S.; Pedersen, B.K.; Ganz, T. IL-6 mediates hypoferremia of inflammation by inducing the synthesis of the iron regulatory hormone hepcidin. J. Clin. Investig. 2004, 113, 1271-1276. [CrossRef] [PubMed]

78. Vela, D. Hepcidin, an emerging and important player in brain iron homeostasis. J. Transl. Med. 2018, 16, 1-18. [CrossRef]

79. Qian, Z.-M.; He, X.; Liang, T.; Wu, K.-C.; Yan, Y.-C.; Lu, L.-N.; Yang, G.; Luo, Q.Q.; Yung, W.-H.; Ke, Y. Lipopolysaccharides Upregulate Hepcidin in Neuron via Microglia and the IL-6/STAT3 Signaling Pathway. Mol. Neurobiol. 2014, 50, 811-820. [CrossRef]

80. Colonna, M.; Butovsky, O. Microglia function in the central nervous system during health and neurodegeneration. Annu. Rev. Immunol. 2017, 35, 441-468. [CrossRef] [PubMed]

81. Chhabra, R.; Saha, A.; Chamani, A.; Schneider, N.; Shah, R.; Nanjundan, M. Iron Pathways and Iron Chelation Approaches in Viral, Microbial, and Fungal Infections. Pharmaceuticals 2020, 13, 275. [CrossRef] [PubMed]

82. Coffey, R.; Ganz, T. Iron homeostasis: An anthropocentric perspective. J. Biol. Chem. 2017, 292, 12727-12734. [CrossRef]

83. Reed-Geaghan, E.G.; Savage, J.C.; Hise, A.G.; Landreth, G.E. CD14 and Toll-Like Receptors 2 and 4 Are Required for Fibrillar A $\beta$-Stimulated Microglial Activation. J. Neurosci. 2009, 29, 11982-11992. [CrossRef]

84. Sfera, A.; Gradini, R.; Cummings, M.; Diaz, E.; Price, A.I.; Osorio, C. Rusty Microglia: Trainers of Innate Immunity in Alzheimer's Disease. Front. Neurol. 2018, 9, 1-16. [CrossRef] 
85. Becerril-Ortega, J.; Bordji, K.; Fréret, T.; Rush, T.; Buisson, A. Iron overload accelerates neuronal amyloid- $\beta$ production and cognitive impairment in transgenic mice model of Alzheimer's disease. Neurobiol. Aging 2014, 35, 2288-2301. [CrossRef] [PubMed]

86. Martinez, F.O.; Gordon, S. The M1 and M2 paradigm of macrophage activation: Time for reassessment. F1000Prime Rep. 2014, 6, 13. [CrossRef]

87. Floden, A.M.; Li, S.; Combs, C.K. $\beta$-Amyloid-stimulated microglia induce neuron death via synergistic stimulation of tumor necrosis factor $\alpha$ and NMDA receptors. J. Neurosci. 2005, 25, 2566-2575. [CrossRef] [PubMed]

88. Brown, G.C.; Neher, J.J. Inflammatory neurodegeneration and mechanisms of microglial killing of neurons. Mol. Neurobiol. 2010, 41, 242-247. [CrossRef] [PubMed]

89. Orihuela, R.; McPherson, C.A.; Harry, G.J. Microglial M1/M2 polarization and metabolic states. Br. J. Pharmacol. 2016, 173, 649-665. [CrossRef] [PubMed]

90. Johnson, E.E.; Wessling-Resnick, M. Iron metabolism and the innate immune response to infection. Microbes Infect. 2012, 14, 207-216. [CrossRef]

91. Nairz, M.; Haschka, D.; Demetz, E.; Weiss, G. Iron at the interface of immunity and infection. Front. Pharmacol. 2014, 5, 152-162. [CrossRef]

92. Nakamura, K.; Kawakami, T.; Yamamoto, N.; Tomizawa, M.; Fujiwara, T.; Ishii, T.; Harigae, H.; Ogasawara, K. Activation of the NLRP3 inflammasome by cellular labile iron. Exp. Hematol. 2016, 44, 116-124. [CrossRef]

93. Liddelow, S.A.; Guttenplan, K.A.; Clarke, L.E.; Bennett, F.C.; Bohlen, C.J.; Schirmer, L.; Bennett, M.L.; Münch, A.E.; Chung, W.-S.; Peterson, T.C.; et al. Neurotoxic reactive astrocytes are induced by activated microglia. Nature 2017, 541, 481-487. [CrossRef]

94. Liddelow, S.A.; Barres, B.A. Reactive Astrocytes: Production, Function, and Therapeutic Potential. Immunity 2017, 46, 957-967. [CrossRef]

95. You, L.H.; Yan, C.Z.; Zheng, B.J.; Ci, Y.Z.; Chang, S.Y.; Yu, P.; Gao, G.F.; Li, H.Y.; Dong, T.Y.; Chang, Y.Z. Astrocyte hepcidin is a key factor in LPS-induced neuronal apoptosis. Cell Death Dis. 2017, 8, e2676. [CrossRef] [PubMed]

96. Fakhoury, M. Microglia and astrocytes in Alzheimer's disease: Implications for therapy. Curr. Neuropharmacol. 2018, 16, 508-518. [CrossRef]

97. Darreh-Shori, T.; Vijayaraghavan, S.; Aeinehband, S.; Piehl, F.; Lindblom, R.P.F.; Nilsson, B.; Ekdahl, K.N.; Långström, B.; Almkvist, O.; Nordberg, A. Functional variability in butyrylcholinesterase activity regulates intrathecal cytokine and astroglial biomarker profiles in patients with Alzheimer's disease. Neurobiol. Aging 2013, 34, 2465-2481. [CrossRef]

98. Kadir, A.; Marutle, A.; Gonzalez, D.; Schöll, M.; Almkvist, O.; Mousavi, M.; Mustafiz, T.; Darreh-Shori, T.; Nennesmo, I.; Nordberg, A. Positron emission tomography imaging and clinical progression in relation to molecular pathology in the first Pittsburgh Compound B positron emission tomography patient with Alzheimer's disease. Brain 2011, 134, 301-317. [CrossRef] [PubMed]

99. Zecca, L.; Youdim, M.B.H.; Riederer, P.; Connor, J.R.; Crichton, R.R. Iron, brain ageing and neurodegenerative disorders. Nat. Rev. Neurosci. 2004, 5, 863-873. [CrossRef] [PubMed]

100. Connor, J.R.; Menzies, S.L.; St. Martin, S.M.; Mufson, E.J. Cellular distribution of transferrin, ferritin, and iron in normal and aged human brains. J. Neurosci. Res. 1990, 27, 595-611. [CrossRef]

101. Connor, J.R.; Snyder, B.S.; Beard, J.L.; Fine, R.E.; Mufson, E.J. Regional distribution of iron and iron-regulatory proteins in the brain in aging and Alzheimer's disease. J. Neurosci. Res. 1992, 31, 327-335. [CrossRef]

102. Ramos, P.; Santos, A.; Pinto, N.R.; Mendes, R.; Magalhães, T.; Almeida, A. Iron levels in the human brain: A post-mortem study of anatomical region differences and age-related changes. J. Trace Elem. Med. Biol. 2014, 28, 13-17. [CrossRef] [PubMed]

103. Ashraf, A.; Clark, M.; So, P.W. The aging of iron man. Front. Aging Neurosci. 2018, 10, 65. [CrossRef] [PubMed]

104. Gaasch, J.A.; Lockman, P.R.; Geldenhuys, W.J.; Allen, D.D.; Van der Schyf, C.J. Brain Iron Toxicity: Differential Responses of Astrocytes, Neurons, and Endothelial Cells. Neurochem. Res. 2007, 32, 1196-1208. [CrossRef] [PubMed]

105. DeGregorio-Rocasolano, N.; Martí-Sistac, O.; Ponce, J.; Castelló-Ruiz, M.; Millán, M.; Guirao, V.; García-Yébenes, I.; Salom, J.B.; Ramos-Cabrer, P.; Alborch, E.; et al. Iron-loaded transferrin (Tf) is detrimental whereas iron-free Tf confers protection against brain ischemia by modifying blood Tf saturation and subsequent neuronal damage. Redox Biol. 2018, 15, 143-158. [CrossRef]

106. Khan, A.I.; Liu, J.; Dutta, P. Iron transport kinetics through blood-brain barrier endothelial cells. Biochim. Biophys. Acta Gen. Subj. 2018, 1862, 1168-1179. [CrossRef] [PubMed]

107. Gunshin, H.; Mackenzie, B.; Berger, U.V.; Gunshin, Y.; Romero, M.F.; Boron, W.F.; Nussberger, S.; Gollan, J.L.; Hediger, M.A. Cloning and characterization of a mammalian proton-coupled metal-ion transporter. Nature 1997, 388, 482-488. [CrossRef] [PubMed]

108. Zhou, Z.D.; Tan, E.-K. Iron regulatory protein (IRP)-iron responsive element (IRE) signaling pathway in human neurodegenerative diseases. Mol. Neurodegener. 2017, 12, 75-87. [CrossRef] [PubMed]

109. Pigeon, C.; Ilyin, G.; Courselaud, B.; Leroyer, P.; Turlin, B.; Brissot, P.; Loréal, O. A New Mouse Liver-specific Gene, Encoding a Protein Homologous to Human Antimicrobial Peptide Hepcidin, Is Overexpressed during Iron Overload. J. Biol. Chem. 2001, 276, 7811-7819. [CrossRef]

110. Verga Falzacappa, M.V.; Vujic Spasic, M.; Kessler, R.; Stolte, J.; Hentze, M.W.; Muckenthaler, M.U. STAT3 mediates hepatic hepcidin expression and its inflammatory stimulation. Blood 2007, 109, 353-358. [CrossRef]

111. Brissot, P.; Pietrangelo, A.; Adams, P.C.; de Graaff, B.; McLaren, C.E.; Loréal, O. Haemochromatosis. Nat. Rev. Dis. Prim. 2018, 4, 18016-18031. [CrossRef] 
112. Holmes, C.; Cunningham, C.; Zotova, E.; Woolford, J.; Dean, C.; Kerr, S.; Culliford, D.; Perry, V.H. Systemic inflammation and disease progression in alzheimer disease. Neurology 2009, 73, 768-774. [CrossRef] [PubMed]

113. Erdei, J.; Tóth, A.; Balogh, E.; Nyakundi, B.B.; Bányai, E.; Ryffel, B.; Paragh, G.; Cordero, M.D.; Jeney, V. Induction of NLRP3 Inflammasome Activation by Heme in Human Endothelial Cells. Oxid. Med. Cell. Longev. 2018, 2018, 1-14. [CrossRef] [PubMed]

114. McCarthy, R.C.; Park, Y.; Kosman, D.J. sAPP modulates iron efflux from brain microvascular endothelial cells by stabilizing the ferrous iron exporter ferroportin. EMBO Rep. 2014, 15, 809-815. [CrossRef]

115. Wong, B.X.; Tsatsanis, A.; Lim, L.Q.; Adlard, P.A.; Bush, A.I.; Duce, J.A. B-Amyloid Precursor Protein Does Not Possess Ferroxidase Activity But Does Stabilize the Cell Surface Ferrous Iron Exporter Ferroportin. PLoS ONE 2014, 9, 1-19. [CrossRef]

116. Galzitskaya, O.V.; Galushko, E.I.; Selivanova, O.M. Studies of the Process of Amyloid Formation by A $\beta$ Peptide. Biochem. 2018, 83, S62-S80. [CrossRef] [PubMed]

117. Puig, K.L.; Combs, C.K. Expression and function of APP and its metabolites outside the central nervous system. Exp. Gerontol. 2013, 48, 608-611. [CrossRef]

118. Matsui, T.; Ingelsson, M.; Fukumoto, H.; Ramasamy, K.; Kowa, H.; Frosch, M.P.; Irizarry, M.C.; Hyman, B.T. Expression of APP pathway mRNAs and proteins in Alzheimer's disease. Brain Res. 2007, 1161, 116-123. [CrossRef]

119. Tyan, S.H.; Shih, A.Y.J.; Walsh, J.J.; Maruyama, H.; Sarsoza, F.; Ku, L.; Eggert, S.; Hof, P.R.; Koo, E.H.; Dickstein, D.L. Amyloid precursor protein (APP) regulates synaptic structure and function. Mol. Cell. Neurosci. 2012, 51, 43-52. [CrossRef]

120. Ling, Y.; Morgan, K.; Kalsheker, N. Amyloid precursor protein (APP) and the biology of proteolytic processing: Relevance to Alzheimer's disease. Int. J. Biochem. Cell Biol. 2003, 35, 1505-1535. [CrossRef]

121. Kojro, E.; Gimpl, G.; Lammich, S.; Marz, W.; Fahrenholz, F. Low cholesterol stimulates the nonamyloidogenic pathway by its effect on the -secretase ADAM 10. Proc. Natl. Acad. Sci. USA 2001, 98, 5815-5820. [CrossRef] [PubMed]

122. Vassar, R. Beta-Secretase Cleavage of Alzheimer's Amyloid Precursor Protein by the Transmembrane Aspartic Protease BACE. Science 1999, 286, 735-741. [CrossRef]

123. Poon, C.H.; Wang, Y.; Fung, M.-L.; Zhang, C.; Lim, L.W. Rodent Models of Amyloid-Beta Feature of Alzheimer's Disease: Development and Potential Treatment Implications. Aging Dis. 2020, 11, 1235-1259. [CrossRef]

124. Piccinelli, P.; Samuelsson, T. Evolution of the iron-responsive element. RNA 2007, 13, 952-966. [CrossRef]

125. Gunshin, H.; Allerson, C.R.; Polycarpou-Schwarz, M.; Rofts, A.; Rogers, J.T.; Kishi, F.; Hentze, M.W.; Rouault, T.A.; Andrews, N.C.; Hediger, M.A. Iron-dependent regulation of the divalent metal ion transporter. FEBS Lett. 2001, 509, 309-316. [CrossRef]

126. Muckenthaler, M.U.; Galy, B.; Hentze, M.W. Systemic Iron Homeostasis and the Iron-Responsive Element/Iron-Regulatory Protein (IRE/IRP) Regulatory Network. Annu. Rev. Nutr. 2008, 28, 197-213. [CrossRef]

127. Rogers, J.T.; Randall, J.D.; Cahill, C.M.; Eder, P.S.; Huang, X.; Gunshin, H.; Leiter, L.; McPhee, J.; Sarang, S.S.; Utsuki, T.; et al. An Iron-responsive Element Type II in the 5'-Untranslated Region of the Alzheimer's Amyloid Precursor Protein Transcript. J. Biol. Chem. 2002, 277, 45518-45528. [CrossRef] [PubMed]

128. Cho, H.-H.; Cahill, C.M.; Vanderburg, C.R.; Scherzer, C.R.; Wang, B.; Huang, X.; Rogers, J.T. Selective Translational Control of the Alzheimer Amyloid Precursor Protein Transcript by Iron Regulatory Protein-1. J. Biol. Chem. 2010, 285, 31217-31232. [CrossRef] [PubMed]

129. Zou, K.; Gong, J.S.; Yanagisawa, K.; Michikawa, M. A Novel Function of Monomeric Amyloid $\beta$-Protein Serving as an Antioxidant Molecule against Metal-Induced Oxidative Damage. J. Neurosci. 2002, 22, 4833-4841. [CrossRef] [PubMed]

130. Cheignon, C.; Tomas, M.; Bonnefont-Rousselot, D.; Faller, P.; Hureau, C.; Collin, F. Oxidative stress and the amyloid beta peptide in Alzheimer's disease. Redox Biol. 2018, 14, 450-464. [CrossRef] [PubMed]

131. Long, J.M.; Maloney, B.; Rogers, J.T.; Lahiri, D.K. Novel upregulation of amyloid- $\beta$ precursor protein (APP) by microRNA-346 via targeting of APP mRNA 5'-untranslated region: Implications in Alzheimer's disease. Mol. Psychiatry 2019, 24, 345-363. [CrossRef]

132. Lockridge, O. Review of human butyrylcholinesterase structure, function, genetic variants, history of use in the clinic, and potential therapeutic uses. Pharmacol. Ther. 2015, 148, 34-46. [CrossRef]

133. Lockridge, O.; Bartels, C.F.; Vaughan, T.A.; Wong, C.K.; Norton, S.E.; Johnson, L.L. Complete amino acid sequence of human serum cholinesterase. J. Biol. Chem. 1987, 262, 549-557. [CrossRef]

134. Johnson, G.; Moore, S.W. Why has butyrylcholinesterase been retained? Structural and functional diversification in a duplicated gene. Neurochem. Int. 2012, 61, 783-797. [CrossRef] [PubMed]

135. Tiethof, A.K.; Richardson, J.R.; Hart, R.P. Knockdown of butyrylcholinesterase but not inhibition by chlorpyrifos alters early differentiation mechanisms in human neural stem cells. Toxics 2018, 6, 52. [CrossRef] [PubMed]

136. Darvesh, S.; Hopkins, D.A.; Geula, C. Neurobiology of butyrylcholinesterase. Nat. Rev. Neurosci. 2003, 4, 131-138. [CrossRef]

137. Mesulam, M.-M.; Guillozet, A.; Shaw, P.; Levey, A.; Duysen, E.; Lockridge, O. Acetylcholinesterase knockouts establish central cholinergic pathways and can use butyrylcholinesterase to hydrolyze acetylcholine. Neuroscience 2002, 110, 627-639. [CrossRef]

138. Darvesh, S.; Grantham, D.L.; Hopkins, D.A. Distribution of butyrylcholinesterase in the human amygdala and hippocampal formation. J. Comp. Neurol. 1998, 393, 374-390. [CrossRef]

139. Darvesh, S.; Hopkins, D.A. Differential distribution of butyrylcholinesterase and acetylcholinesterase in the human thalamus. J. Comp. Neurol. 2003, 463, 25-43. [CrossRef]

140. Darreh-Shori, T.; Forsberg, A.; Modiri, N.; Andreasen, N.; Blennow, K.; Kamil, C.; Ahmed, H.; Almkvist, O.; Långström, B.; Nordberg, A. Differential levels of apolipoprotein E and butyrylcholinesterase show strong association with pathological signs of Alzheimer's disease in the brain in vivo. Neurobiol. Aging 2011, 32, e15-e32. [CrossRef] 
141. Darvesh, S.; Cash, M.K.; Reid, G.A.; Martin, E.; Mitnitski, A.; Geula, C. Butyrylcholinesterase Is Associated with $\beta$-Amyloid Plaques in the Transgenic APPSWE/PSEN1dE9 Mouse Model of Alzheimer Disease. J. Neuropathol. Exp. Neurol. 2012, $71,2-14$. [CrossRef]

142. Reid, G.A.; Darvesh, S. Butyrylcholinesterase-knockout reduces brain deposition of fibrillar $\beta$-amyloid in an Alzheimer mouse model. Neuroscience 2015, 298, 424-435. [CrossRef] [PubMed]

143. Mesulam, M.; Geula, C. Butyrylcholinesterase reactivity differentiates the amyloid plaques of aging from those of dementia. Ann. Neurol. 1994, 36, 722-727. [CrossRef] [PubMed]

144. Geula, C.; Mesulam, M.-M. Cholinesterases and the Pathology of Alzheimer Disease. Alzheimer Dis. Assoc. Disord. 1995, 9, 23-28. [CrossRef] [PubMed]

145. Gómez-Ramos, P.; Bouras, C.; Morán, M.A. Ultrastructural localization of butyrylcholinesterase on neurofibrillary degeneration sites in the brains of aged and Alzheimer's disease patients. Brain Res. 1994, 640, 17-24. [CrossRef]

146. Guillozet, A.L.; Mesulam, M.-M.; Smiley, J.F.; Mash, D.C. Butyrylcholinesterase in the life cycle of amyloid plaques. Ann. Neurol. 1997, 42, 909-918. [CrossRef]

147. Jasiecki, J.; Jońca, J.; Żuk, M.; Szczoczarz, A.; Janaszak-Jasiecka, A.; Lewandowski, K.; Waleron, K.; Wasag, B. Activity and polymorphisms of butyrylcholinesterase in a Polish population. Chem. Biol. Interact. 2016, 259, 70-77. [CrossRef] [PubMed]

148. Brissot, P.; Troadec, M.-B.; Loréal, O.; Brissot, E. Pathophysiology and classification of iron overload diseases; update 2018. Transfus. Clin. Biol. 2019, 26, 80-88. [CrossRef]

149. Ganz, T. Erythropoietic regulators of iron metabolism. Free Radic. Biol. Med. 2019, 133, 69-74. [CrossRef]

150. Elliott, S.; Pham, E.; Macdougall, I.C. Erythropoietins: A common mechanism of action. Exp. Hematol. 2008, 36, 1573-1584. [CrossRef]

151. Furlow, P.W.; Percy, M.J.; Sutherland, S.; Bierl, C.; McMullin, M.F.; Master, S.R.; Lappin, T.R.J.; Lee, F.S. Erythrocytosis-associated HIF- $2 \alpha$ Mutations Demonstrate a Critical Role for Residues C-terminal to the Hydroxylacceptor Proline. J. Biol. Chem. 2009, 284, 9050-9058. [CrossRef]

152. Zimmer, M.; Ebert, B.L.; Neil, C.; Brenner, K.; Papaioannou, I.; Melas, A.; Tolliday, N.; Lamb, J.; Pantopoulos, K.; Golub, T.; et al. Small-Molecule Inhibitors of HIF-2a Translation Link Its 5'UTR Iron-Responsive Element to Oxygen Sensing. Mol. Cell 2008, 32, 838-848. [CrossRef]

153. Lappin, T.R.; Lee, F.S. Update on mutations in the HIF: EPO pathway and their role in erythrocytosis. Blood Rev. 2019, 37, 100590100599. [CrossRef] [PubMed]

154. Campillos, M.; Cases, I.; Hentze, M.W.; Sanchez, M. SIREs: Searching for iron-responsive elements. Nucleic Acids Res. 2010, 38, 360-367. [CrossRef]

155. Jasiecki, J.; Limon-Sztencel, A.; Żuk, M.; Chmara, M.; Cysewski, D.; Limon, J.; Wasag, B. Synergy between the alteration in the $\mathrm{N}$-terminal region of butyrylcholinesterase K variant and apolipoprotein E4 in late-onset Alzheimer's disease. Sci. Rep. 2019, 9, 5223. [CrossRef] [PubMed]

156. Jońca, J.; Zuk, M.; Wasag, B.; Janaszak-Jasiecka, A.; Lewandowski, K.; Wielgomas, B.; Waleron, K.; Jasiecki, J. New insights into butyrylcholinesterase activity assay: Serum dilution factor as a crucial parameter. PLoS ONE 2015, 10, e0139480. [CrossRef]

157. Liu, J.-L.; Fan, Y.-G.; Yang, Z.-S.; Wang, Z.-Y.; Guo, C. Iron and Alzheimer's Disease: From Pathogenesis to Therapeutic Implications. Front. Neurosci. 2018, 12, 632. [CrossRef]

158. Nuñez, M.T.; Chana-Cuevas, P. New perspectives in iron chelation therapy for the treatment of neurodegenerative diseases. Pharmaceuticals 2018, 11, 109. [CrossRef]

159. Guo, C.; Wang, T.; Zheng, W.; Shan, Z.-Y.; Teng, W.-P.; Wang, Z.-Y. Intranasal deferoxamine reverses iron-induced memory deficits and inhibits amyloidogenic APP processing in a transgenic mouse model of Alzheimer's disease. Neurobiol. Aging 2013, 34, 562-575. [CrossRef]

160. Banerjee, P.; Sahoo, A.; Anand, S.; Ganguly, A.; Righi, G.; Bovicelli, P.; Saso, L.; Chakrabarti, S. Multiple Mechanisms of IronInduced Amyloid Beta-Peptide Accumulation in SHSY5Y Cells: Protective Action of Negletein. NeuroMol. Med. 2014, 16, 787-798. [CrossRef]

161. McLachlan, D.R.C.; Kruck, T.P.A.; Kalow, W.; Andrews, D.F.; Dalton, A.J.; Bell, M.Y.; Smith, W.L. Intramuscular desferrioxamine in patients with Alzheimer's disease. Lancet 1991, 337, 1304-1308. [CrossRef] 